\title{
Article
}

\section{The impact of in-service physical injury or illness on the mental health of military veterans}

Hynes, Celia, Scullion, L, Lawler, C, Steel, Rebecca and Boland, Paul

Available at https://clok.uclan.ac.uk/37092/

Hynes, Celia, Scullion, L, Lawler, C, Steel, Rebecca and Boland, Paul orcid iconORCID: 0000-0003-2267-4295 (2021) The impact of in-service physical injury or illness on the mental health of military veterans. BMJ Military Health . ISSN 2633-3767

It is advisable to refer to the publisher's version if you intend to cite from the work. http://dx.doi.org/10.1136/bmjmilitary-2020-001759

For more information about UCLan's research in this area go to http://www.uclan.ac.uk/researchgroups/ and search for <name of research Group>.

For information about Research generally at UCLan please go to http://www.uclan.ac.uk/research/

All outputs in CLoK are protected by Intellectual Property Rights law, including Copyright law. Copyright, IPR and Moral Rights for the works on this site are retained by the individual authors and/or other copyright owners. Terms and conditions for use of this material are defined in the policies page.

\section{CLoK}

Central Lancashire online Knowledge www.clok.uclan.ac.uk

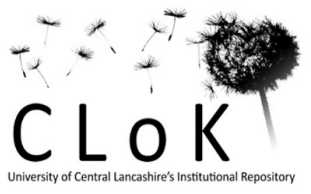


This article has been accepted for publication in Accronym not defined in the Dictionary following peer review. The definitive copyedited, typeset version is available online at $10.1136 / \mathrm{bmjmilitary}$

The impact of in-Service physical injury or illness on the mental health of military veterans

\section{Abstract \\ Background}

Each year approximately 2000 UK service personnel are medically discharged with physical and/or psychological injury or illness. While there is much research on both psychological injury and physical injury, the challenges of transition relating to the intersection between the two has received less attention. This article reports on the first phase of a two-year funded study with the aim to understand the lived experiences of veterans who have been discharged from service with a physical injury or illness and the impacts of this on their mental health.

Methods

Using a qualitative methodology, 22 veterans who had been discharged from service within the last eight years were interviewed to identify key aspects of their experience of the transition process.

Results

The article highlights two key themes: how some veterans adjusted to life with a physical injury or condition; and, the intersections that became apparent between physical injury and mental health. The challenges that veterans faced were shaped not only by the transition process, but also by the way in which the medical discharge process was conducted.

\section{Conclusions}

Consideration of improvements to the medical discharge process could influence better outcomes for those who have left with a physical injury or illness and later find themselves struggling with mental health issues.

\section{Key messages}

Discharge due to physical injury or illness can have long term implications for mental health

The discharge and subsequent transition process can impact on veteran wellbeing over a significant period of time There is a need for mental health support both before and after discharge for Service Personnel with physical injuries or conditions

\section{Introduction}

Each year approximately 14,000 personnel leave the Armed Forces, of whom about 2,000 are wounded, injured and sick (WIS) (1,2). Data suggests that the percentages for physical injuries leading to discharge are much higher than those attributed to mental health $(1,3)$. Indeed, over the period from April 2014 to March 2019, musculoskeletal disorders (MSDs) alone accounted for $59 \%$ of discharges from both the Army and Navy, and 48\% of discharges from the RAF (1).

Much existing research provides important quantitative data on the prevalence and impact of particular conditions and injuries, e.g., musculoskeletal conditions $(4,5)$, traumatic brain injuries (TBI) (6-10), and limb loss (11-13); however, we recognise that behind the statistics are individual Service leavers who are adjusting to life with a physical condition/injury. For those who acquire a physical injury or condition while in Service, there may be a requirement for medical discharge relatively quickly, whereas others may experience an initial downgrading of their role, followed by a subsequent medical discharge (or in some cases voluntarily leaving Service) (14).

Previous studies show that some veterans can experience frustration, confusion and poor psychosocial integration when discharged due to a physical injury/condition. These experiences relate to a number of factors, including the difficulties adjusting to the shift from being 'able-bodied' to 'disabled' (15), difficulties with accessing civilian health services (16), and the adjustment required 
in relation to a career change (17). All of the aforementioned, together with the experience of chronic pain and unexplained symptoms may lead to feelings of anxiety and stress contributing to mental ill health (18). There has been recognition of the stigma surrounding access to mental health support (19), of the support needs of those with diagnosed mental health issues (such as PTSD) (2022), and that early Service leavers should be given support with their mental health to mitigate later issues (23). However, the lived experiences of those making the transition to civilian life with a Service acquired physical injury or condition and how their physical health impacts on their mental ill health remains largely unknown $(5,22)$. Our study therefore provides important insights for policy and practice in relation to how veterans narrate the intersections between their physical and mental health (24).

\section{Methods}

Purposive non-random sampling techniques (25) were used to recruit our veteran participants. Recruitment was supported by a diverse range of organisations, using the following inclusion criteria: having served in the British Armed Forces, having left Service since 2012, and having a physical condition as a direct result of, or acquired during, Service. The timeframe of eight years was chosen for a number of practical reasons: to correlate with the timeframe of both the literature review and changes that were made to the transition process, and to ensure sufficient time had lapsed since the height of conflicts in Afghanistan and Iraq so that the sample of participants was not dominated by those who had been critically wounded and/or traumatised.

As part of a wider longitudinal study on people both who had already left Service and who were in the process of leaving Service, a total of 22 veteran participants were interviewed between October 2019 and May 2020. The interviews lasted approximately 60-90 minutes, and the majority took place face-to-face, though a small number were undertaken via telephone due to availability and preference. The interviews focused on providing a comprehensive overview of each person's health condition, how they had experienced discharge from the Armed Forces, and how they had subsequently experienced the transition to civilian life. The interviews were audio recorded and transcribed verbatim. Analysis was undertaken by three members of the research team who were each given an allocation of transcripts for analysis. Prior to analysis, the researchers had met to agree the themes and the approach to coding, i.e. thematic analysis (9), and to ensure consistency in the approach. To protect anonymity, each participant was given an identifying code, beginning with 'WIS', and all identifying information was removed from quotes before their use.

As a qualitative study, we do not claim to be representative of the WIS veteran population. Rather, our study aimed to reflect the diversity of physical injuries/conditions that can be acquired during Service, and the diverse challenges that accompany such injuries/conditions. Table 1 below provides an overview of our sample of ex-Service Personnel. The 'Injury/condition summary' lists the conditions that participants stated were attributed to, or had been acquired during, Service. Injuries/conditions had occurred due to a number of activities (combat, training) or cumulatively over time. It should also be noted that, while some participants had PTSD listed as one of the reasons for their discharge, our inclusion criteria stated that the primary reason for discharge was a physical condition.

\section{Table 1: Veteran sample}

\begin{tabular}{l|l|l|l|l|l|l}
$\begin{array}{l}\text { Participant } \\
\text { code }\end{array}$ & Gender & Age & $\begin{array}{l}\text { Armed } \\
\text { Forces } \\
\text { Service }\end{array}$ & $\begin{array}{l}\text { Service } \\
\text { length } \\
\text { (yrs) }\end{array}$ & $\begin{array}{l}\text { Time since } \\
\text { leaving } \\
\text { Service }\end{array}$ & Injury/condition summary \\
\hline WIS 1 & Male & 37 & RAF & 8 & 8 years & Foot injury.
\end{tabular}




\begin{tabular}{|c|c|c|c|c|c|c|}
\hline WIS 2 & Male & $\begin{array}{l}\text { Not } \\
\text { given }\end{array}$ & Army & 38 & 4 years & $\begin{array}{l}\text { Osteoarthritis (legs/hips), hip } \\
\text { degeneration, spinal } \\
\text { degenerative disease. }\end{array}$ \\
\hline WIS 3 & Male & 31 & Army & 4.5 & 4.5 years & $\begin{array}{l}\text { Complications after leg surgery } \\
\text { for a suspected varicose vein. }\end{array}$ \\
\hline WIS 5 & Female & $\begin{array}{l}\text { Not } \\
\text { given }\end{array}$ & RAF & 12 & 4 years & $\begin{array}{l}\text { Downgrading due to pregnancy. } \\
\text { Voluntary discharge. }\end{array}$ \\
\hline WIS 6 & Male & 40 & Army & 16 & 7 years & Hearing loss. \\
\hline WIS 7 & Male & 40 & Army & 18 & $\begin{array}{l}\text { In discharge } \\
\text { process }\end{array}$ & $\begin{array}{l}\text { Ankle injuries, hip fracture, quad } \\
\text { damage, nerve damage, hernia. }\end{array}$ \\
\hline WIS 8 & Male & 34 & Army & 15 & $\begin{array}{l}\text { In discharge } \\
\text { process }\end{array}$ & Back injury. \\
\hline WIS 10 & Female & 37 & RAF & 10 & 1 month & $\begin{array}{l}\text { Breast cancer, chronic fatigue } \\
\text { syndrome. }\end{array}$ \\
\hline WIS 11 & Female & 32 & Royal Navy & 3 & 8 years & $\begin{array}{l}\text { Hip and spine injury, Chronic } \\
\text { Regional Pain Syndrome. }\end{array}$ \\
\hline WIS 12 & Male & 42 & Army & 17 & 4 years & Back injury. \\
\hline WIS 13 & Male & 44 & Army & 20 & 2 years & Back injury. \\
\hline WIS 14 & Male & 38 & RAF & 18 & 1 year & $\begin{array}{l}\text { Back injury, slipped discs, Achilles } \\
\text { injury, knee injury. }\end{array}$ \\
\hline WIS 15 & Female & 42 & $\begin{array}{l}\text { RAF and } \\
\text { Army }\end{array}$ & 22 & 1 year & Hip problems, tendonitis. \\
\hline WIS 18 & Male & 47 & Army & 21 & 4 years & $\begin{array}{l}\text { Knee injury, heel injury, back } \\
\text { pain. }\end{array}$ \\
\hline WIS 19 & Male & 56 & Army & 39 & 4 months & Knee injury. \\
\hline WIS 21 & Male & 47 & $\begin{array}{l}\text { Royal Navy } \\
\text { and Royal } \\
\text { Marines }\end{array}$ & 7 & 19 years & $\begin{array}{l}\text { Double knee injury, spine } \\
\text { damage, slight loss of hearing } \\
\text { and sight. }\end{array}$ \\
\hline WIS 22 & Male & $\begin{array}{l}\text { Not } \\
\text { given }\end{array}$ & Army & 10 & $\begin{array}{l}\text { In discharge } \\
\text { process }\end{array}$ & Shoulder injury. \\
\hline WIS 26 & Male & 36 & Army & 13 & 6 years & $\begin{array}{l}\text { Lower back and leg injuries, } \\
\text { PTSD. }\end{array}$ \\
\hline WIS 27 & Female & 44 & $\begin{array}{l}\text { Army } \\
\text { reserve }\end{array}$ & 4 & 2 years & Knee injury. \\
\hline WIS 31 & Male & 65 & RAF & 30 & 10 years & Knee injury. \\
\hline
\end{tabular}




\begin{tabular}{|l|l|l|l|l|l|l|}
\hline WIS 32 & Male & $\begin{array}{l}\text { Not } \\
\text { given }\end{array}$ & Army & 37 & 8 months & Heart problem, PTSD. \\
\hline WIS 37 & Male & 41 & Army & 16 & 7 years & Ulcerative colitis. \\
\hline
\end{tabular}

\section{Results}

\section{Adjusting to life with a physical injury/condition}

Similar to the existing data referred to above, MSDs were prevalent across our sample. However, regardless of the nature of the condition/injury, all participants described a difficult process of having to adapt to their condition. For a number of veterans, it was evident that their physical condition/injury imposed limitations on their ability to carry out routine (and taken for granted) everyday tasks, but also limitations to their civilian employment prospects. This required people making both practical and mental adaptations to address these issues:

I massively have to restrict my lifestyle now. I used to go and do a lot of running. I don't do that so much... and then just making sensible life choices. I bought my car, I got an automatic, I just found it easier. Emptying the tumble dryer, I've got a little stool thing like that that I sit on, and just little things, don't stand in one position too long, don't sit too long (WIS 8).

You sit back and you think, 'what am I going to do, it's like I can't work on tools any more, I can't work overhead, I've got to be careful with the weather when it's cold...' You're trying to mitigate all the problems that you're going to face... I can't do any of that ever again [referring to roles within the Armed Forces], and I'm now in office work (WIS 22).

However, the impacts of managing day-to-day life were not just related to them as an individual, and it was evident that there were often significant knock-on effects on relationships with spouses and children. The account of the veteran below illustrates this in detail. This participant had recently been discharged from the RAF due to a back injury, but also had secondary issues relating to his knees and Achilles tendon. These physical conditions had fundamentally impacted upon his role as a father, but also on his spouse who was his primary carer:

I wake up in pain. Getting down the stairs, the house I'm going to have to buy now is a bungalow, because I can't go up and down stairs easily. In fact, coming downstairs is getting harder and harder... I get up in the morning, and then I go downstairs, and then I don't go back upstairs until I go to bed, which is hard because I've got kids and, at the moment, my wife's working, so I'm the sole care provider, really for my one-year-old ... I can't go for long walks... no more than 200 metres...I can walk to the shop and back, and then I have to sit down for a while, and then obviously that affects what I then do with my son. I can't pick my [four-year-old] daughter up, which, that's horrible for anyone. When I used to throw my eldest son around the pool in Cyprus, I can't do any of that with any of the children. Basically, I can't really cook because I can't bend down into the oven. My wife's my carer, really (WIS 14).

\section{Intersections between physical injury and mental health}

A common theme across our interviews was a complex interplay between adjusting to life with a physical injury/condition and the consequent impact on participants' mental health. Indeed, many participants described experiencing a deterioration in their mental health since their injury or 
condition - and the subsequent discharge from the Armed Forces. In some cases, people made reference to suicidal thoughts - though it should be noted that no participants had made an attempt to take their own life, and that the research team had access to a range of organisations that they could refer participants to if support was required.

I think I'm still a little bit depressed now, to be honest about it, because your back plays up and you're thinking, 'well, I'm letting my family down, letting myself down', but it's not my fault I understand that. At one stage in my transition I thought about ending it, but... with no real conviction. I thought, 'I'd be better off if I weren't here'. I had a couple of rough days thinking, 'what am I going to do...?' I miss the Army every day (WIS 13).

However, it was evident that for some participants a deterioration in mental health was not just experienced upon entering civilian life. In some cases, it began while they were still in Service, often in cases where attempts had been made to continue with their normal duties while injured, or where they had been downgraded for a period of time, before being discharged. For example, one participant described how injuries to his hip and spine - and the consequent loss of ability - had been the catalyst for a 'breakdown' during his rehabilitation period. Now, as a veteran, he indicated that this manifested as aggression:

"I'd been for rehab after surgery, and I broke down in that. I was broken. I was absolutely broken. My mental capacity had just gone ... I suffer with road rage. I suffer with shoppingtrolley-aisle rage, anybody in my way... get panic attacks around people; my temper goes up. I've never done anything wrong, I've never hit anybody, don't get me wrong, I feel sometimes I want to just smash people out of the way. I have no tolerance for anybody, nothing. I used to be one of the most tolerable, likeable blokes. I look in the mirror and I don't know who I am. I hate myself every day for what I've become." (WIS 2)

Another participant described seeking pre-discharge treatment for anxiety and low mood, due to limited support with the discharge process and a feeling of being 'pushed out':

I fell through a lot of cracks, which obviously didn't do my head too well...constant pushing from my line manager saying I was leaving [due to physical injury], that led to the start of the anxiety issues and the low mood. A month or so before I came out, I started being treated for that low mood, depression aspect of things, because I just felt broken inside, not just physically, but mentally as well (WIS 1 ).

Many participants looked back on their career in the Armed Forces with a significant sense of pride; however, in some cases their perceptions of the Armed Forces had been 'tainted' by their experience of being injured:

"For the first 13, 14 years of my career, I was volunteering to go everywhere, deploying on everything, all the tours, keen as mustard...Just loved it, loved deploying and then, when my injury got bad and I was saying, 'Look, I need to, this is what I need to do now', just it becomes a different, nasty, horrible environment. Psychologically, that's bad. It makes you feel really low, you have low self-esteem... You're just stood there, and people are running past you going, 'Look at the biff', it's just such a bad, negative environment if you're injured in the Army" (WIS 8)

On this environmental aspect, several participants spoke of the sudden change in their feeling of 'membership' within the Armed Forces once they had been injured - with some describing feeling "abandoned" or "segregated". Participants contextualised their experience of injury with reference 
to a perceived 'culture' within the Armed Forces - to "man up" and "griz through it", which appeared to be at odds with subsequent transition experiences where veterans were required to acknowledge and discuss their injuries in order to access support.

\section{Discussion}

Service Personnel who are medically discharged with a physical injury or condition face a number of compounding challenges: they firstly have to contend with an injury or condition which often has life-changing impacts; secondly, they are losing their careers in the Armed Forces along with what that means to them (e.g. service, belonging, camaraderie); and thirdly, they are facing the often sudden and unexpected transition to civilian life, with all of the consequent changes in, decisions about, and planning around finances, skills, employment, housing, etc., for themselves and their families (14). It is therefore unsurprising that this process may have an impact on mental health.

How they experienced the process of discharge, and follow-up after discharge, greatly impacted on the participants in this study. Indeed, it appeared that experiences in civilian life differed depending on how they perceived the medical discharge process was managed. Those who were experiencing the most significant difficulties in the transition to civilian life were those for whom the process was described as being highly stressful, unclear and confusing and with what they

felt was inadequate time and support to prepare for leaving the Armed Forces.

Although focusing on the experiences of veterans, our study also demonstrates the blurred line in relation to pre and post discharge experiences of mental ill health. This raises concerns around the need to ensure appropriate support is provided during the medical discharge and resettlement process. The experiences of our participants reiterate the findings of existing research highlighting the need to improve the mental health assessment of those who are being discharged with a physical injury (26). Furthermore, the culture of self-sufficiency ingrained in Service personnel plays a significant role in whether and how they access support during the transition to civilian life. Participants felt there should be ongoing follow-up of veterans to ensure that they weren't ' $f$ alling through the cracks' potentially opened up by leaving Service and trying to navigate civilian life with a physical injury/condition.

\section{Conclusions}

Our research provides important insights into the lived experiences of those who have left Service with a physical injury/condition, revealing aspects of the, transition process where improvements could be made to existing policy and practice. Participants' accounts demonstrated a need to provide greater mental health support to those medically discharged with a physical injury or condition, both before and after discharge. Ensuring that the medical discharge process is fully understood by those experiencing it, with appropriate time to prepare for civilian life, would improve the overall experiences of Service leavers, and mitigate some of the difficulties that can occur in the transition process.

\section{References}

1. MOD. Annual medical discharges in the UK Regular Armed Forces, 1 April 2014 to 31 March 2019 [Internet]. 2019 Jul [cited 2020 Dec 10]. Available from: https://assets.publishing.service.gov.uk/government/uploads/system/uploads/attachment_dat a/file/909874/20200814_-_MedicalDisBulletinFinal_-_O.pdf

2. Scullion L, Dwyer P, Jones K, Martin P, Hynes C. Sanctions, Support \& Service Leavers. Social Security benefits, welfare conditionality and transitions from military to civilian life. First-wave findings [Internet]. 2018 p. 50. Available from: http://www.fim-trust.org/wp- 
content/uploads/2018/04/20180410-FiMT-Sanctions-Support-Service-Leavers-InterimReport.pdf

3. Bergman BP, Miller SA. Unfit for further service: trends in medical discharge from the British Army 1861-1998. J R Army Med Corps. 2000 Oct;146(3):204-11.

4. Sharma J, Greeves JP, Byers M, Bennett AN, Spears IR. Musculoskeletal injuries in British Army recruits: a prospective study of diagnosis-specific incidence and rehabilitation times. BMC Musculoskelet Disord. 2015 May 4;16(1):106.

5. Kelsall HL, McKenzie DP, Forbes AB, Roberts MH, Urquhart DM, Sim MR. Pain-related musculoskeletal disorders, psychological comorbidity, and the relationship with physical and mental well-being in Gulf War veterans. PAIN ${ }^{\circledR} .2014$ Apr 1;155(4):685-92.

6. Hawley CA, de Burgh HT, Russell RJ, Mead A. Traumatic brain injury recorded in the UK Joint Theatre Trauma Registry among the UK Armed Forces. J Head Trauma Rehabil. 2015 Feb;30(1):E47-56.

7. Rona RJ, Jones M, Fear NT, Hull L, Murphy D, Machell L, et al. Mild traumatic brain injury in UK military personnel returning from Afghanistan and Iraq: cohort and cross-sectional analyses. J Head Trauma Rehabil. 2012 Feb;27(1):33-44.

8. Sigurdardottir S, Andelic N, Roe C, Jerstad T, Schanke A-K. Post-concussion symptoms after traumatic brain injury at 3 and 12 months post-injury: a prospective study. Brain Inj. 2009 Jun;23(6):489-97.

9. Scherer MR, Burrows H, Pinto R, Littlefield P, French LM, Tarbett AK, et al. Evidence of central and peripheral vestibular pathology in blast-related traumatic brain injury. Otol Neurotol Off Publ Am Otol Soc Am Neurotol Soc Eur Acad Otol Neurotol. 2011 Jun;32(4):571-80.

10. Elder GA, Ehrlich ME, Gandy S. Relationship of traumatic brain injury to chronic mental health problems and dementia in military veterans. Neurosci Lett. 2019 Aug 10;707:134294.

11. Gaunaurd IA, Roach KE, Raya MA, Hooper R, Linberg AA, Laferrier JZ, et al. Factors related to high-level mobility in male servicemembers with traumatic lower-limb loss. J Rehabil Res Dev. 2013;50(7):969-84.

12. Desmond DM, MacLachlan M. Coping strategies as predictors of psychosocial adaptation in a sample of elderly veterans with acquired lower limb amputations. Soc Sci Med 1982. 2006 Jan;62(1):208-16.

13. Krueger CA, Wenke JC, Ficke JR. Ten years at war: comprehensive analysis of amputation trends. J Trauma Acute Care Surg. 2012 Dec;73(6 Suppl 5):S438-444.

14. Heaver L, McCullough K, Briggs L. Lifting the Lid on Transition: The families' experience and the support they need. Forces in Mind Trust; 2018.

15. Caddick N, Smith B. Exercise is medicine for mental health in military veterans: a qualitative commentary. Qual Res Sport Exerc Health. 2017;10(4):429-40.

16. Christensen J, Langberg H, Doherty P, Egerod I. Ambivalence in rehabilitation: thematic analysis of the experiences of lower limb amputated veterans. Disabil Rehabil. 2017;40(21):2553-60. 
17. Brunger H, Serrato J, Ogden J. "No man's land": the transition to civilian life. J Aggress Confl Peace Res. 2013;5(2):86-100.

18. Blakey SM, Wagner HR, Naylor J, Brancu M, Lane I, Sallee M, et al. Chronic Pain, TBI, and PTSD in Military Veterans: A Link to Suicidal Ideation and Violent Impulses? J Pain. 2018 Jul;19(7):797806.

19. Sharp M-L, Fear NT, Rona RJ, Wessely S, Greenberg N, Jones N, et al. Stigma as a barrier to seeking health care among military personnel with mental health problems. Epidemiol Rev. 2015;37:144-62.

20. Kovačić Petrović Z, Peraica T, Eterović M, Anđelinović M, Kozarić-Kovačić D. Combat Posttraumatic Stress Disorder and Quality of Life: Do Somatic Comorbidities Matter? J Nerv Ment Dis. 2019 Feb;207(2):53-8.

21. Browne T, Hull L, Horn O, Jones M, Murphy D, Fear NT, et al. Explanations for the increase in mental health problems in UK reserve forces who have served in Iraq. Br J Psychiatry J Ment Sci. 2007 Jun;190:484-9.

22. Sharp M-L, Busuttil W, Murphy D. Examining physical health conditions and associations of pain, obesity, and function of UK Veterans diagnosed with PTSD and other mental health conditions. J Mil Veteran Fam Health. 2019 Sep 1;5(2):75-87.

23. Buckman JEJ, Forbes HJ, Clayton T, Jones M, Jones N, Greenberg N, et al. Early Service leavers: a study of the factors associated with premature separation from the UK Armed Forces and the mental health of those that leave early. Eur J Public Health. 2013 Jun;23(3):410-5.

24. Samele C. The mental health of serving and ex-Service personnel: A review of the evidence and perspectives of key stakeholders.

25. Mason J. Qualitative researching. London: Sage; 2002.

26. Help for Heroes. Improving the medical discharge process [Internet]. 2019. Available from: https://www.helpforheroes.org.uk/media/yenp2mov/2019_0053-medical-discharge-policypaper-v3.pdf 